\section{Factors Affecting the Income of Palm Sugar SMEs in Kaidipang District, North Bolaang Mongondow Regency}

Delya Yustika Buhang ${ }^{1}$, Sri Endang Saleh ${ }^{2}$, Sri Indriyani Dai ${ }^{3}$

${ }^{1}$ Economic Faculty, Universitas Negeri Gorontalo, Indonesia

${ }^{2}$ Economic Faculty, Universitas Negeri Gorontalo, Indonesia

${ }^{3}$ Economic Faculty, Universitas Negeri Gorontalo, Indonesia

\section{Email: delyabuhang300@gmail.com}

Abstract: This study aims to determine the factors that influence the income of palm sugar SMEs in Kaidipang District, North Bolaang Mongondow Regency. This type of research is survey research. Survey research is research that takes a sample from one population and uses a questionnaire as the main data collection tool. The types of data used in this research are primary data and secondary data. primary data is data obtained directly from the first source of the field in the form of data obtained through interviews. The results of the study show that capital has a positive but not significant effect on the income of SMEs. Capital has a positive effect on the income of SMEs. The number of workers has a positive and significant effect on the income of SMEs in North Bolaang Mongondow district. Raw materials have a positive but not significant effect on MSME income. The level of education has a negative effect on the income of palm sugar SMEs. Technology has a positive but not significant effect on the income of palm sugar SMEs. MSME Income $=4.739+0.065$ Capital + 0.298 Total Labor + 0.132 Raw Materials - 0.079 Education Level + 0.162 Technology $+e$

Keywords: Income; Capital; Labor; Raw Materials; Education
Article History:

Received on 10 Jan 2022

Revised on 12 Jan 2022

Accepted on 15 Jan 2022

Doi: 10.37479

Indexing:

Google Scholar; Asean

Citation

Index; Copernicus; SINTA

5 (Science And

Technology Index)

The journal allows the authors to hold the copyright without restrictions and allow the authors to retain publishing rights without restrictions. international license.

\title{
INTRODUCTION
}

National development has placed humans at a central point so that they have characteristics from the people, by the people and for the people, development has a broad meaning as a multidimensional process that includes important changes in social structures, attitudes of society and national institutions. and local as well as accelerating economic growth, reducing inequality, and eradicating poverty (Todaro, 2000:20). The development that occurs in various sectors essentially leads to the expansion of opportunities for those who are not able to adopt all qualified workers.

Micro, Small and Medium Enterprises (MSMEs) are small business units that function as safety valves both in providing alternative productive business activities, alternative lending, as well as in terms of employment. The economic crisis that occurred in Indonesia in 1998 is proof that the MSME sector is the strength of Indonesia's creative economy. The creative economy, which is based on the creativity of creative resources, has the opportunity to encourage the competitiveness of the Indonesian nation in the future.

Along with the development of Indonesia today, there are many business actors or people who open businesses, both micro, small and medium scale businesses. One of them is in the North Bolaang Mongondow district, especially in the village of Pontak itself, the development of Micro, Small and Medium Enterprises (MSMEs) is relatively fast. Where these developments are spread in a number of areas of North Bolaang Mongondow covering 6 sub-districts and almost all Micro, Small and Medium Enterprises (MSMEs) are under the auspices of the local Regency Government's Cooperatives and Micro, Small and Medium Enterprises (UMKM) Office. With the empowerment and development carried out by the Office of Cooperatives and Micro, Small and Medium Enterprises (MSMEs), it is hoped that businesses in North Bolaang Mongondow Regency can compete with businesses from outside the city and the income that continues to rise from year to year is increasingly felt by the community. business owner. 
Realizing the importance of the role of MSMEs, efforts are made to empower MSMEs in the context of accelerating regional and central economic development and increasing the competitiveness of MSME products. The MSME sector often utilizes resources from agriculture, plantations, livestock and trade. The MSME sector is referred to as the people's economy because the results of MSMEs are goods needed for the daily life of every community. In its development, Micro, Small and Medium Enterprises are still faced with various problems, for example the Iow productivity of MSMEs, limited access of MSMEs to productive sources, such as capital, technology, markets and information, and the non-conducive business climate for MSMEs. Facing the era of globalization and business competition, MSMEs need to improve the quality of their respective businesses.

Based on initial observations, the researchers found that most small and medium businesses were running, including food stalls, kiosks, palm sugar and many more spread over 6 sub-districts. In this study, researchers only focused on Palm Sugar SMEs, especially in Kaidipang District. Palm Sugar SMEs are already widely spread in Kaidipang District. But that does not mean that in running this business there are no obstacles, a business will certainly face many obstacles, especially in maintaining and developing its business so it takes patience and tenacity and high creativity so that it can compete with other entrepreneurs. The development of SMEs in Kaidipang District from year to year always experiences a very rapid increase. This is driven by the ability of each SME actor to maintain the business they run. For more details, see the table on the development of Palm Sugar in Kaidipang District.

Based on data from the Office of Cooperatives and SMEs in Kaidipang District, in 2019 the number of Palm Sugar UKM workers was 121 people. With a capital of Rp. 5,000,000 each, each SME player began to run a palm sugar business with the existing capital. In addition, it can be seen that although the amount of capital is the same, the income earned by SMEs is different. This is due to the large number of workers besides of course the skills and expertise of each SME actor which will also affect the amount of palm sugar produced. A large workforce can certainly help produce an item or business product. A skilled and competitive workforce will provide satisfactory results. Especially now that many customers are observant in choosing good quality palm sugar and according to the wishes of the customers so that customers are more likely to buy good quality palm sugar. Because like now a lot of palm sugar produced quality is still not in accordance with the wishes of customers. The existing workforce is mostly high school, vocational, and undergraduate graduates. In addition, Information Technology in the IT sector is also an obstacle faced by SMEs, this is because there is still a lack of knowledge in the IT sector from UKM actors themselves. Mastery of IT is very helpful in running a business, especially in terms of obtaining raw materials. SMEs in Kaidpang District still use manual steps, namely by visiting directly or still looking for raw materials to be used in the production of goods or products.

Based on the description above, the hypothesis in this study is as follows: Education, Capital, Labor, raw materials, and technology have a positive effect on the income of Palm Sugar SMEs in Kaidipang District, North Bolaang Mongondow Regency.

\section{METHODOLOGY}

The location of this research is located in North Bolaang Mongondow Regency, precisely in Kaidipang District, North Bolaang Mongondow Regency. Kaidipang sub-district has 9 sub-districts, namely: Pontak, Inomunga, Solo, Komus II, Kuala Utara, Boroko, East Boroko, and Bigo. This type of research is survey research. Survey research is research that takes a sample from one population and uses a questionnaire as the main data collection tool. This study uses multiple linear regression analysis with the following formula:

$$
Y=a+\beta_{1} X_{1}+\beta_{2} X_{2}+\beta_{3} X_{3}+\beta_{4} X_{4}+\beta_{5} X_{5}+\beta_{6} X_{6} \beta n+X n+e
$$

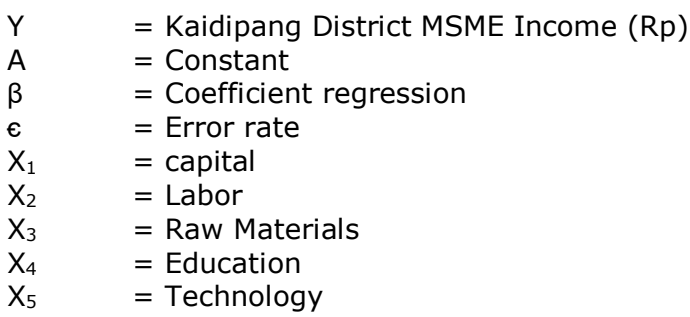

\section{DISCUSSION}

\section{Effect of Capital on MSME Income}

Based on the results of the analysis that has been obtained previously, it shows that capital has a positive effect on MSME income. The higher the capital issued will increase the income of MSMEs. However, capital is not significant to MSME income. This means that the capital issued is not necessarily able to increase the income of MSMEs. This proves that capital is not the main factor supporting the progress of a MSME. These results also prove that the palm sugar SMEs in North Bolaang Mongondow are mostly using their business capital and have not been targeted. From the results of research in the field, only a few MSMEs use capital for business 
development. In addition, palm sugar MSMEs utilize their business capital to only focus on providing raw materials, without equipping the tools and technology to support production.

\section{Effect of the Labor on MSME Income}

Based on the research that has been done previously, the results show that the number of workers has a positive and significant effect on the income of SMEs in the North Bolaang Mongondow district. This means that every increase in the number of workers can increase the income of palm sugar SMEs in North Bolaang Mongondow Regency. The more the number of workers in a business, it can directly increase output or production results. With high production results obtained can reap more income. These results prove that the palm sugar MSME workforce in North Bolaang Mongondow district is well fulfilled. However, even so, the problem that occurs in the field is that the workforce is less skilled or less able to encourage productivity as expected. However, this is not an obstacle for palm sugar SMEs from developing. Because by utilizing existing tools and technology, the output produced by this MSME workforce will not decrease and even increase in line with consumer demand. With the presence of palm sugar SMEs in North Bolaang Mongondow district, it is hoped that they can absorb a lot of workers. This study is in line with research conducted by (Putri et.al, 2014) which shows that the number of workers has a positive and significant effect on business income. This is different from the research conducted by (Polandos, et.al, 2019) which states that the number of workers does not have a positive and significant effect on the income of MSME entrepreneurs.

\section{Effect of Raw Materials on MSME Income}

From the results of the analysis that has been done previously, it shows that raw materials have a positive but not significant effect on the income of MSMEs. This means that any increase in the use of raw materials will not necessarily increase the income of palm sugar SMEs in North Bolaang Mongondow Regency. These results prove that not all the raw materials of the marketed products can be accepted by consumers. The raw material used by palm sugar SMEs in North Bolaang Mongondow Regency is mostly water sap. With the use of nira water as a raw material, it may not be accepted by consumers because of several factors, one of which is the texture, shape or taste of palm sugar using these raw materials may be different. The high income of SMEs is due to the increasing demand for palm sugar by consumers. However, if the palm sugar produced is not as desired by consumers, it will indirectly affect the income level of the SME. This research is in line with research conducted by (Nayaka, et.al, 2018) where the results of his research show that there is a positive influence of raw materials on the income of industrial entrepreneurs. In addition, research conducted by Dwi Lestari (2019) also states that raw materials have a positive effect on MSME income.

\section{Effect of Education Level on MSME Income}

From the results of the analysis that has been done previously, it is found that the level of education has a negative effect on the income of palm sugar SMEs. This means that every increase in the level of education will reduce the income of palm sugar SMEs in the North Bolaang Mongondow district. This is clearly the case because a person's level of education can basically increase his income. The level of education in this study is more devoted to MSME actors, especially MSME workers. The level of education possessed by this MSME workforce will affect the resulting output. Knowledge and high work experience will improve the quality of output so that the demand for palm sugar products will increase and have a direct effect on the income of palm sugar SMEs in North Bolaang Mongondow district. Theoretically, the level of education should be able to improve performance and income for MSMEs themselves. However, this may not happen due to factors of low education, knowledge and low work experience. Therefore, from some of the explanations that have been put forward, it proves that the level of education does not necessarily reduce the income of palm sugar SMEs in the North Bolaang Mongondow district. This research is in line with research by Saraswati (2008) and Utari, et.al (2014) which states that simultaneously the level of education has a significant effect on the income of MSMEs.

\section{Effect of Technology on SME Income}

From the results of the analysis that has been done previously, the results show that technology has a positive but not significant effect. This means that every technological improvement does not necessarily increase the income of palm sugar SMEs in the North Bolaang Mongondow district. This phenomenon is possible because the palm sugar SMEs in the North Bolaang Mongondow Regency have not utilized the existing technology. Utilization of good technology can simplify, accelerate and increase production results. Not only that, marketing techniquesby utilizing technology must be put to good use. Online buying and selling transactions are currently very easy for consumers and producers. In addition, we can use technology to find information and business development references. The only way to get palm sugar SME actors in North Bolaang Mongondow Regency is to make more use of existing technology to gain big profits. This study is in line with research conducted by Utari et.al (2014) which states that there is a positive relationship between technology and MSME income. However, it is different from the research conducted by Hasana et al (2020) which states that simultaneously technological materials have a significant effect on MSME income. 


\section{CONCLUSION}

From the results of the analysis that has been obtained previously, in this study the authors draw the following conclusions:

1. Capital has a positive effect on MSME income. The higher the capital issued will increase the income of MSMEs. However, capital is not significant to MSME income. This means that the capital issued is not necessarily able to increase the income of MSMEs.

2. The number of workers has a positive and significant effect on the income of SMEs in the North Bolaang Mongondow district. This means that every increase in the number of workers can increase the income of palm sugar SMEs in North Bolaang Mongondow Regency.

3. Raw materials have a positive but not significant effect on MSME income. This means that any increase in the use of raw materials will not necessarily increase the income of palm sugar SMEs in North Bolaang Mongondow Regency.

4. The level of education has a negative effect on the income of palm sugar SMEs. This means that every increase in the level of education will reduce the income of palm sugar SMEs in the North Bolaang Mongondow district. However, the level of education is not significant to the income of SMEs, meaning that the level of education may not necessarily reduce the income of palm sugar SMEs in North Bolaang Mongondow district.

5. Technology has a positive but not significant effect on the income of palm sugar SMEs. Every technological improvement does not necessarily increase MSME income.

\section{REFERENCES}

Agusmidah, 2010, Dinamika Hukum Ketenaga kerjaan Indonesia, Medan : USU Press

Ahmad Tanzeh,2009, Pengantar Metode Penelitian, Yogyakarta : Teras,

Alyas dan Muhammad Rakib, Strategi Pengembangan Usaha Mikro, Kecil Dan Menengah Dalam Penguatan Ekonomi Kerakyatan (Studi Kasus pada Usaha Roti Maros di Kabupaten Maros Sekokah Tinggi IImu Ekonomi Yayasan Pendidikan Ujung Pandang, Sosiohumaniora, Volume 19 No. 2 Juli 2017 : $114-120$

Arikunto, Suharsimi. 2006. Prosedur Penelitian Suatu Pendekatan Praktik. Jakarta: Rineka Cipta.

Chandra Budi,2013.,Jutaan UMKM Pahlawan Pajak Urus Pajak itu Sangat Mudah, ( Jakarta : PT Elex Komputindo,

Darmawan, D. (2012). "Pendidikan Teknologi Informasi dan Komunikasi". Bandung. PT Remaja Rosdakarya

Dwi lestari. 2019. Pengaruh modal,jumlah tenaga kerja dan bahan baku terhadap pendapatan usaha mikro, kecil dan menengah (UMKM) makanan ringan di kabupaten tulungagung,skripsi.fakultas dan bisnis islam IAIN tulungangung.

Fajri Ismail, Statistika untuk Penelitian Pendidikan dan Ilmu-ilmu Sosial, (Jakarta : Prenadamedia Group, 2018

Husein Umar,2000Riset Pemasaran dan Perilaku Konsumen, Jakarta: PT Gramedia Pustaka Utama,

Husen Umar, 2014 Metode Penelitian untuk Skripsi dan Tesis Bisnis, Jakarta : PT. Raja Grafindo Persada,

Hadi Noviono, Dyah Pelitawati, 2020 Pengaruh Modal Kerja, Pendidikan Dan Teknologi Terhad ap Pendapatan Usaha Mikro Kecil Dan Menengah (Umkm) Di Sentra Industri Tas Dan Koper Tanggulangin, Universitas WR. Supratman Surabaya, di akses Tanggal 18 November pukul 19.52

Hafsah, M. J. 2004. Upaya Pengembangan Usaha Mikro, Kecil dan Menengah (UMKM). Jurnal Infokop. Nomor 25 Tahun XX.

Hasanah,R.L Kholifah, D.N.,pengaruh modal,tingkat pendidikan dan tekhnologi terhadap pendapatan UMKM kabupaten purbalingga.KINERJA,

Komang Widya Nayaka, Nengah Kartika,2020, Pengaruh Modal, Tenaga Kerja Dan Bahan Baku Terhadap Pendapatan Pengusaha Industri Sanggah Di Kecamatan Mengwi, Fakultas Ekonomi dan Bisnis Universitas Udayana, Bali, Indonesia,E-Jurnal Ekonomi dan Bisnis Universitas Udayana 7.8 (2018): 1927-1956 di akses Tanggal 18 November pukul 19.52

Kasmir, Kewirausahaan, Jakarta : PT Raja Grafindo Persada, 2006.

Kartika Putri, et,all,"Pengaruh Karakteristik Kewirausahaan, Modal Usaha dan Peran Bussiness Development Service terhadap Pengembangan Usaha (Studi pada Sentra Industri Kerupuk Desa Kedungrejo Sidoarjo 
Jawa Timur)", Jurnal Ilmu Administrasi Bisnis, Vol.3, No.4, 2014, hal.4. diakses tanggal 16 pukul 15:00 tahun 2020

Misbahuddin dan Iqbal Hasan,2013Analisis Data Penelitian dengan Statistik Edisi ke 2 ,Cetaka 2, Jakart: :Bumi Aksara,

Margono, 2014Metodologi Penelitian untuk Skripsi dan Tesis Penelitian, (Jakarta : PT. Raja Grafindo Persada,

Nursalam (2003). Konsep dan Penerapan Metodologi Penelitian Ilmu Keperawatan Pedoman Skripsi, Tesis dan Instrumen Penelitian Keperawatan. Jakarta : Salemba Medika.

Nayaka,K,W.,Kartika,I nengah.2018 pengaruh modal dan bahan baku terhadap pendapatan pengusaha industry sanggah di kecamatan mengwi.E-jurnal ekonomidan bisnis UNUD,vol, 7 no 8,hal.1927-1956.

Ramadhani, R. (2013). Komunikasi Interpersonal Orang Tua dan Anak dalam Membentuk Perilaku Positif Anak pada Murid SDIT Cordova Samarinda. eJournal Ilmu Komunikasi, 1 (3), 112-121.

Suryana. 2014. Kewirausahaan, Edisi IV. Jakarta: Salemba Empat.

Suharsimi Arikunto, 2010, Prosedur Penelitian: Suatu Pendekatan Praktik, Jakarta:PT Rineka Cipta,

Sugiyono,2016 Metode Penelitian Kuantitatif ,Kualitatif Dan Kombinasi, (Bandung: Alfabeta,

Sugiyono, Sutopo (ed), 2015, Metodologi Penelitian Kombinasi (Mixed Methods), (Bandung Alfabeta,

Sukidin dan Mundir, Metode Penelitian Membimbing, Mengantar Kesuksesan Anda dalam Dunia Penelitia , (Surabaya : Insan Cendika, 2005

Sutarman. 2009. Pengantar teknologi Informasi. Jakarta : Bumi Aksara.

Wulan Ayodya, 2016, Business Plan Usaha Kuliner Skala UMKM, (Jakarta : PT Elex Media Komputindo Kelompok Gramedia,

Tulus Tambunan, 2012, Usaha Mikro Kecil dan Menengah di Indonesia, (Jakarta: LP3ES,

Todaro, P. M. (2000). Pembangunan ekonomi di dunia ketiga. Jakarta: Penerbit Erlangga.

Utari,tri dewi,P.M.2014 pengaruh modal dan tingkat pendidikan dan tekhnologi terhadap pendapatan usaha mikro kecil dan menengah (UMKM)dikawasan Imam bonjol denpasar barat. E-jurnal EP Unud, vol.3,No 12, hal.576-585. 